\title{
Mycoplasma canadense, a New Bovine Species
}

\author{
E. V. LANGFORD, H. LOUISE RUHNKE, AND O. ONOVIRAN ${ }^{1}$ \\ Animal Pathology Division, Health of Animals Branch, Agriculture Canada, Animal Diseases Research \\ Institute (Western), Lethbridge, Alberta T1J 3Z4; Ontario Ministry of Agriculture and Food, Veterinary \\ Services Branch, Guelph, Ontario; and Department of Veterinary Microbiology and Immunology, University \\ of Guelph, Guelph, Ontario, Canada
}

\begin{abstract}
Three mycoplasmas isolated from the male bovine genital tract and a mastitic udder exhibited serological properties which distinguished them from any of the known Mycoplasma species. Further, a variety of serological procedures failed to identify these organisms with any of the wide range of members of the order Mycoplasmatales tested. These strains are described as belonging to a new species, for which we propose the name Mycoplasma canadense. Strain 275C, designated as the type strain, has been deposited in the National Collection of Type Cultures, Great Britain, under the number 10152.
\end{abstract}

Three Mycoplasma strains, one of which has been reported previously (15), have been characterized but they could not be identified with any known bovine species. These strains and 27 others were found to constitute a separate serological group.

The purpose of this paper is to validly publish the name and to provide a description of the new species to which these strains have been allocated.

\section{MATERIALS AND METHODS}

Bacterial strains. The Mycoplasmatales strains used in this study were supplied by the National Collection of Type Cultures, Public Health Laboratories, London, England; by J. M. Al Aubaidi, as representative of species reported by him (1); and by the National Institutes of Health, Bethesda, Md. Strain $275 \mathrm{C}$ was recovered from the prepuce of a bull, strain $383 \mathrm{C}$ was from semen processed for artificial insemination, and strain 466 was from the mastitic udder of a cow. A list of the strains and species studied is presented in Table 1.

Staining procedures. Staining procedures were as described previously by Langford and Leach (9).

Media. Hayflick medium composed of PPLO broth (HB) or agar (HA) was modified from previously published formulations (9) to contain 0.024 calf thymus deoxyribonucleic acid (Sigma Chemical Company, no. D-1501) per $100 \mathrm{ml}$.

Metabolism tests. Metabolic activity was determined by the methods of Aluotto et al. (2) employing broth medium at $\mathrm{pH} 7.6$ supplemented with $0.5 \%$ glucose, mannitol, mannose, maltose, lactose, salicin, sucrose, arabinose, dulcitol, and sorbitol, $0.5 \%$ arginine at $\mathrm{pH} 7.2$, and urea at $\mathrm{pH} 7.0$.

Reduction of methylene blue, tellurite, and tetrazolium was observed directly by the methods of Aluotto et al. (2). Phosphatase, oxidase, and catalase reactions were determined by the methods of $\mathrm{Al}$ -

\footnotetext{
1 Present address: Federal Department of Veterinary Research, VOM, Nigeria.
}

uotto et al. (2). Determination of the reaction on egg yolk medium was as described by Fabricant and Freundt (6).

Growth requirements. Serum requirements were determined by the method previously reported by Langford and Leach (9) except that the inoculum in each case consisted of organisms washed in serumfree broth media, followed by a wash in $1 \mathrm{M}$ phosphate-buffered saline ( $\mathrm{pH} 7.3$ ), and suspended in serum-free broth at one-half of the initial volume. Growth in the presence of $20 \%$ human, porcine, bovine, lapine, guinea pig, or ovine serum was determined with the same type of inoculum, substituting one of the above in HA and HB. Cholesterol requirements were determined as previously reported (9), but with arginine substituted for glucose.

Inhibition by digitonin and sodium polyethane sulfonate. Inhibition tests were performed as described by Rosendal (13).

Colonial hemadsorption test. The colonial hemadsorption test was performed by the method described by Del Giudice et al. (4).

Hemolysis tests. The test for hemolysis was similar to that described by Somerson et al. (16). Human, rabbit, guinea pig, sheep, horse, chicken, and bovine erythrocytes were used.

Filtration studies. A 24-h-old broth culture was titrated, and $2.5 \mathrm{ml}$ was passed through membrane filters (Millipore Corp.) with the following nominal pore diameters: $800,650,450$, and $220 \mathrm{~nm}$. Serial 10 fold dilutions of the filtrates were made in arginine broth and incubated for 5 days at $37 \mathrm{C}$ before reading.

Cloning. Cloning was done by filtering a culture through a 450-nm filter and plating the filtrate. Several single, well-isolated colonies were picked and transferred to individual broths by Pasteur pipette. The broths were incubated for $48 \mathrm{~h}$ and the procedure was repeated three more times.

Bacterial reversion. The initial broth containing the inhibitors penicillin and thallium acetate in which strain $275 \mathrm{C}$ grew was replated on HA devoid of inhibitors. Colonies with the morphology of classical mycoplasmas were picked to individual tubes 
TABLE 1. Mycoplasmas and acholeplasmas and their antisera used in growth-inhibition and other serological tests

\begin{tabular}{|c|c|}
\hline Strains & $\begin{array}{l}\text { Antisera pro- } \\
\text { vided by }\end{array}$ \\
\hline 1. $275 \mathrm{C}$ & ADRI \\
\hline 2. $383 \mathrm{C}$ & ADRI \\
\hline 3. 466 & H. L. Ruhnke \\
\hline $\begin{array}{l}\text { 4. Mycoplasma mycoides subsp. my- } \\
\text { coides (PG1) }\end{array}$ & $\mathbf{R L}$ \\
\hline 5. M. bovigenitalium (PG 11) & RL \& ADRI \\
\hline 6. Acholeplasma laidlawii (PG 8) & RL \& ADRI \\
\hline 7. $M$. bovirhinis (5M331) & RL \& ADRI \\
\hline 8. M. agalactiae subsp. bovis (Donetta) & ADRI \& RL \\
\hline 9. A. modicum (Squire) & RL \& ADRI \\
\hline 10. Mycoplasma sp. (Group 7) (N29) & RL \& ADRI \\
\hline 11. M. alkalescens (D12) & RL \& ADRI \\
\hline 12. M. dispar (462/2) & RL \& ADRI \\
\hline 13. M. arginini (G230) & RL \& ADRI \\
\hline 14. M. bovoculi (M165/69) & RL \& ADRI \\
\hline 15. M. gateae $(12 \mathrm{PA})^{a}$ & ADRI \\
\hline 16. M. gallinarum (B142P) ${ }^{a}$ & ADRI \\
\hline 17. M. verecundum (107) & ADRI \\
\hline 18. $M$. conjunctivae (M164/69) & ADRI \\
\hline 19. M. gallisepticum (PG 13) & ADRI \\
\hline 20. M. hominis (PG 21) & NIH \\
\hline 21. M. salivarium (PG 20) & NIH \\
\hline 22. M. orale (Ch 19299) & NIH \\
\hline 23. M. agalactiae subsp. bovis (PG 45) & NIH \\
\hline 24. M. gallinarum (PG 16) & NIH \\
\hline 25. M. alkalescens (DBS 803) & NIH \\
\hline 26. M. iners (PG 30) & NIH \\
\hline 27. M. meleagridis (17529) & NIH \\
\hline 28. M. spumans (PG 13) & NIH \\
\hline 29. M. maculosum (PG 15) & NIH \\
\hline 30. M. arthritidis (PG 6) & NIH \\
\hline 31. $M$. fermentans (PG 18) & NIH \\
\hline 32. M.pneumoniae & NIH \\
\hline 33. M. anatis (1340) & NIH \\
\hline 34. $M$. neurolyticum Type A & NIH \\
\hline 35. M. pulmonis (GP 34) & NIH \\
\hline 36. M. hyorhinis (BTS 7) & NIH \\
\hline 37. $M$. canis (PG 14) & NIH \\
\hline 38. A. laidlawii (PG 9) & NIH \\
\hline 39. A. granularum (BTS-39) & NIH \\
\hline 40. M. agalactiae & Plum Island \\
\hline 41. M. mycoides subsp. capri & H. Ernø \\
\hline 42. M. synoviae & Plum Island \\
\hline 43. M. ovipneumoniae & Cottew \\
\hline 44. Mycoplasma sp. (B144 P) & ADRI \\
\hline 45. A. axanthum (H86N) & ADRI \\
\hline
\end{tabular}

${ }^{a}$ Abbreviations: ADRI, Animal Diseases Research Institute (Western), Lethbridge, Alberta, Canada; RL, R. H. Leach (prepared at Wellcome Research Laboratories, Beckenham, Kent, England); NIH, National Institutes of Health, Bethesda, Md

${ }^{\circ}$ Provided by J. Al-Aubaidi.

and passaged seven times through non-inhibitor broth and agar for a total of 15 passages.

OF test. Glucose agar was used according to the method of Aluotto et al. (2).

Temperature requirements. Vials containing 20 $\mathrm{ml}$ of Hayflick broth inoculated with $2 \times 10^{3}$ organisms were incubated at $22,30,35,37.5,40$, and $42 \mathrm{C}$. Tenfold titrations in arginine broth were made after $6,24,48,72,96$, and $120 \mathrm{~h}$ of incubation.

Film and spot production. Film and spot production was determined as previously described by Fab- ricant and Freundt (6) and Langford and Leach (9).

$G+C$ content of DNA. The guanine plus cytosine $(\mathrm{G}+\mathrm{C})$ content of deoxyribonucleic acid (DNA) was determined by the method of Marmur (10).

Antisera. The antisera used were in part those used in a previous characterization study (9). Sera against Mycoplasma bovoculi, M. gateae, M. gallinarum, $M$. conjunctivae, $M$. gallisepticum, $M$. verecundum, Acholeplasma axanthum, Al Aubaidi strain B144P, and strains $275 \mathrm{C}$ and $383 \mathrm{C}$ were prepared in rabbits in essentially the same manner. Antiserum against strain 466 was prepared by the method of Al Aubaidi and Fabricant (1). Sera against 21 other strains were supplied by the $\mathrm{Na}$ tional Institutes of Health, Bethesda, Md. (Table 1).

Metabolic-inhibition tests. Metabolic-inhibition tests were carried out by the method of TaylorRobinson et al. (18) or of Purcell et al. (11), depending on whether the strains catabolized glucose or hydrolyzed arginine.

Growth-inhibition test. Approximately $0.1 \mathrm{ml}$ of a titrated broth culture containing $10^{5}$ colony-forming-units (CFU) per ml was spread evenly over HA, 4 to $5 \mathrm{~mm}$ deep in a $55-\mathrm{mm}$ plastic petri dish. The inoculated plates were air dried. Wells, $5 \mathrm{~mm}$ in diameter, were cut in the agar, and $0.05 \mathrm{ml}$ of each of the test antisera was placed in separate wells. Zones of inhibition were measured from the edge of the well to the zone of growth.

Growth-precipitation tests. Growth-precipitation tests were carried out as described by Ernø and Jurmanova (5), but the wells were partially filled with $0.1 \mathrm{ml}$ of $\mathrm{HA}$ before the inoculum was added. The antisera-impregnated disks were added after 16 to $18 \mathrm{~h}$ of incubation.

Indirect immunofluorescence test. The indirect immunofluorescence test was carried out as described by Rosendal and Black (14).

Counterimmunoelectrophoresis tests. Counterimmunoelectrophoresis tests were carried out by the method of Cho and Langford (3).

Electron microscopy. The method of electron microscopy was similar to that reported previously by Langford and Leach (9). The pictures were taken with a Hitachi model HU-12A at an accelerating voltage of $75 \mathrm{kV}$. The sections were stained with lead acetate and uranyl acetate.

\section{RESULTS}

Morphological characteristics. The test strains $(275 \mathrm{C}, 466$, and $383 \mathrm{C}$ ) had the typical colonial morphology of classical Mycoplasma strains (Fig. 1). Giemsa-stained impression films of colonies (Fig. 2) showed that the colonies were as previously described for other mycoplasmas (17).

Light microscopy of Giemsa-stained films prepared from broth cultures of three strains revealed minute coccoid and bipolar elements with large ring, signet-ring, and other pleomorphic forms. The organisms were gram negative, taking up the counterstain poorly. Electron microscopy of thin sections of strains $275 \mathrm{C}$ 


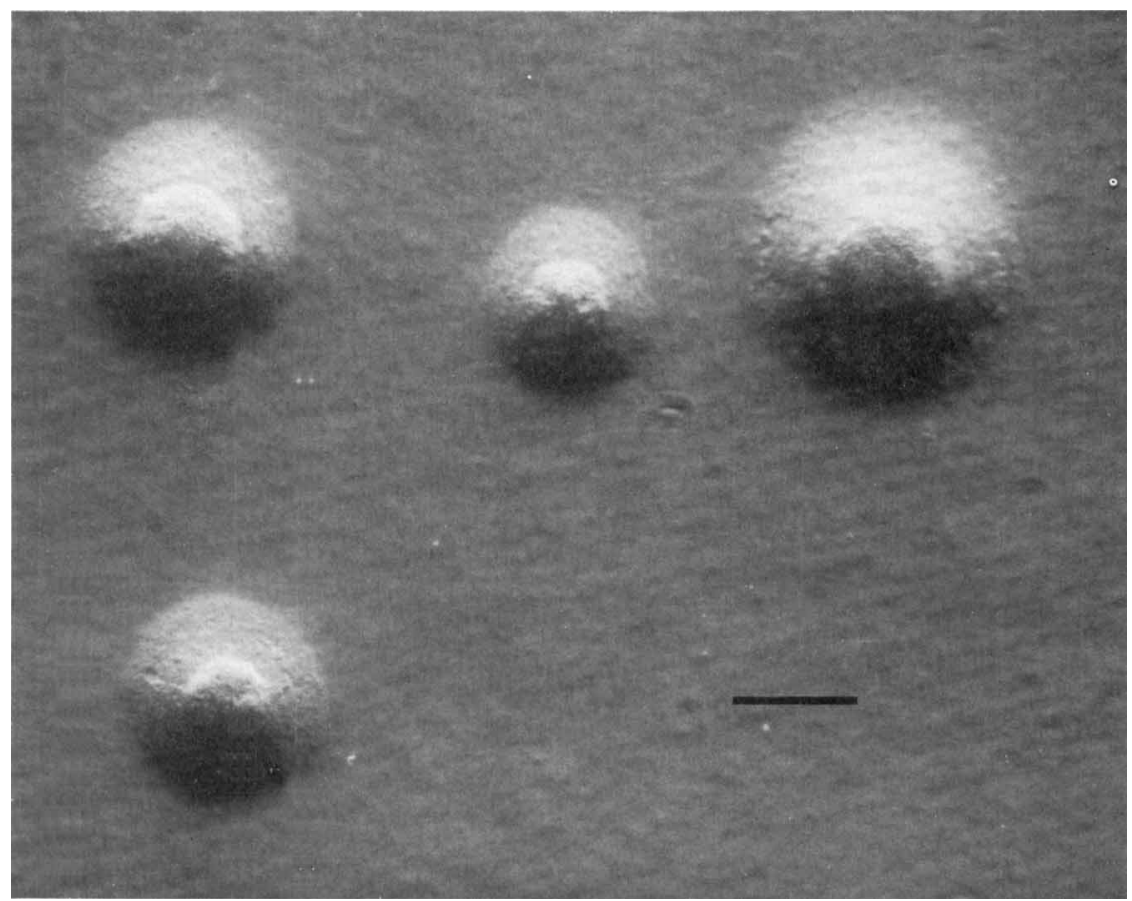

Fig. 1. A 48-h-old colony of Mycoplasma canadense on Hayflick agar. Bar equals $100 \mu \mathrm{m}$.

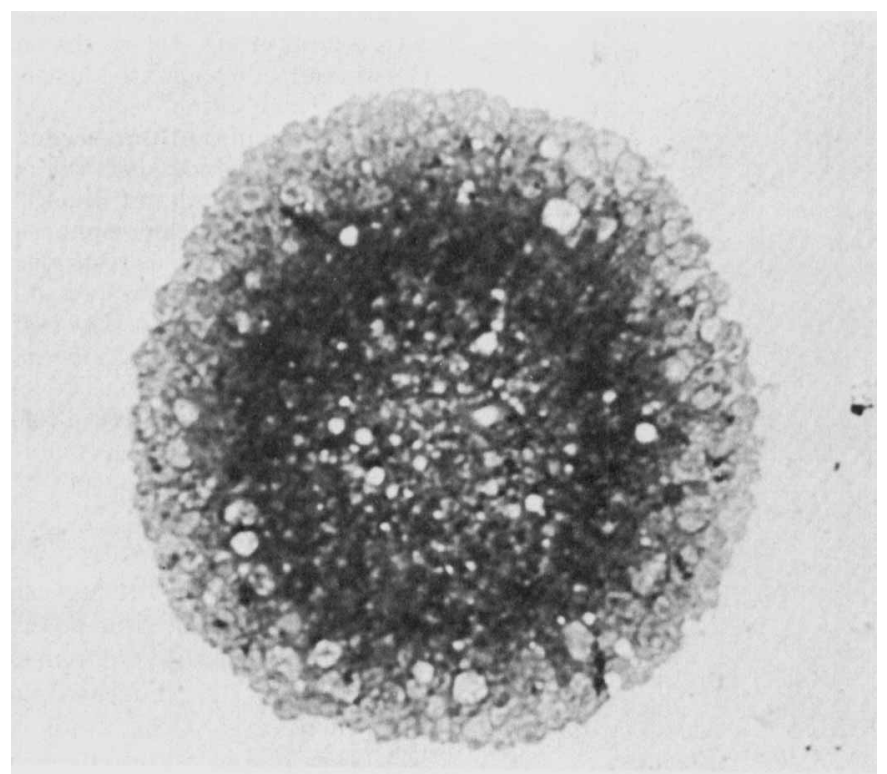

FiG. 2. Giemsa-stained, 24- $h$-old colony of Mycoplasma canadense. $\times 250$.

and $383 \mathrm{C}$ confirmed the absence of a cell wall and the presence of a triple-layered membrane approximately $12 \mathrm{~nm}$ thick (Fig. 3 and 4), as described for mycoplasmas (12). There was no evidence of morphological instability after 15 successive passages through media devoid of bacterial and mycological inhibitors.

Serum-cholesterol requirements. Serum (horse) was required for growth at the $2 \%$ level in both broth and agar; no growth was observed 


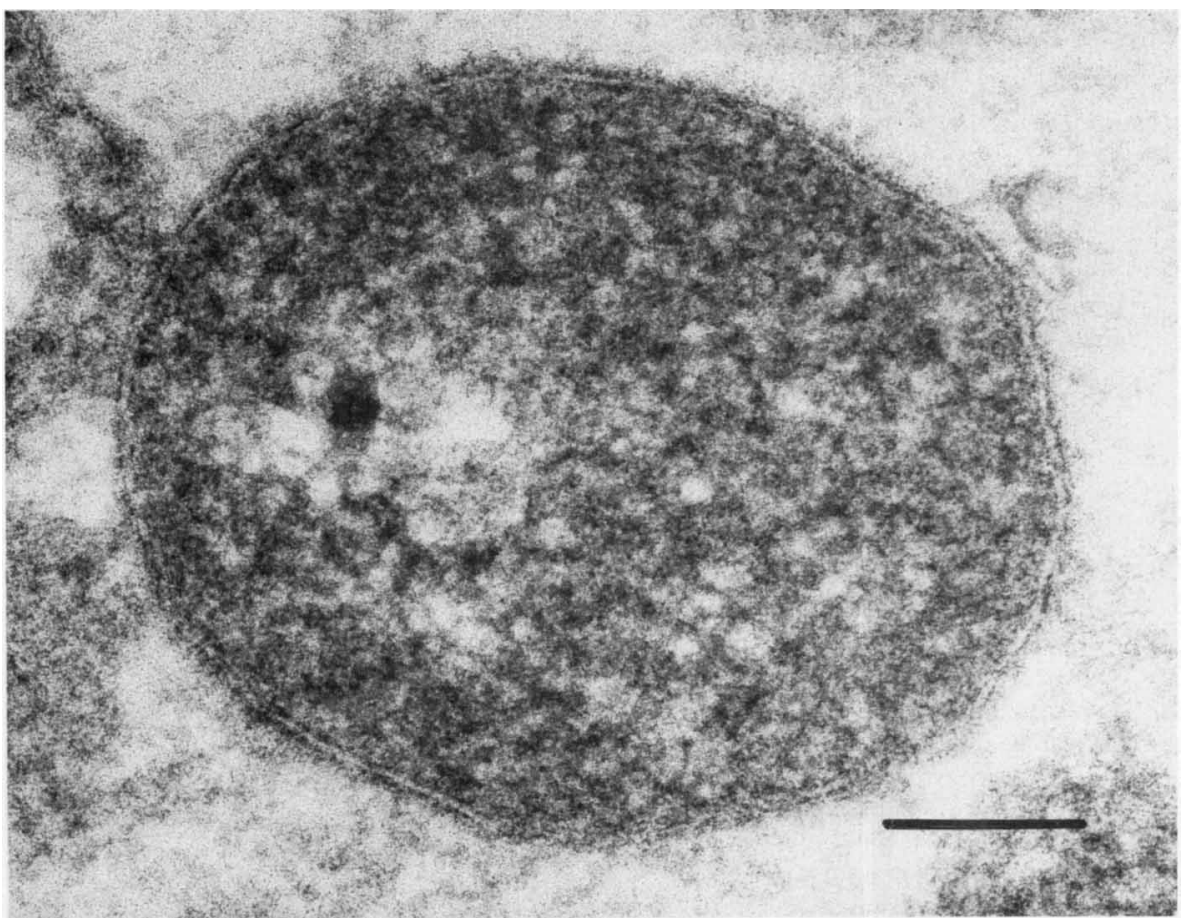

Fig. 3. Electron micrograph of a thin-section preparation of strain $275 \mathrm{C} . \times 200,000$. Bar equals $100 \mathrm{~nm}$.

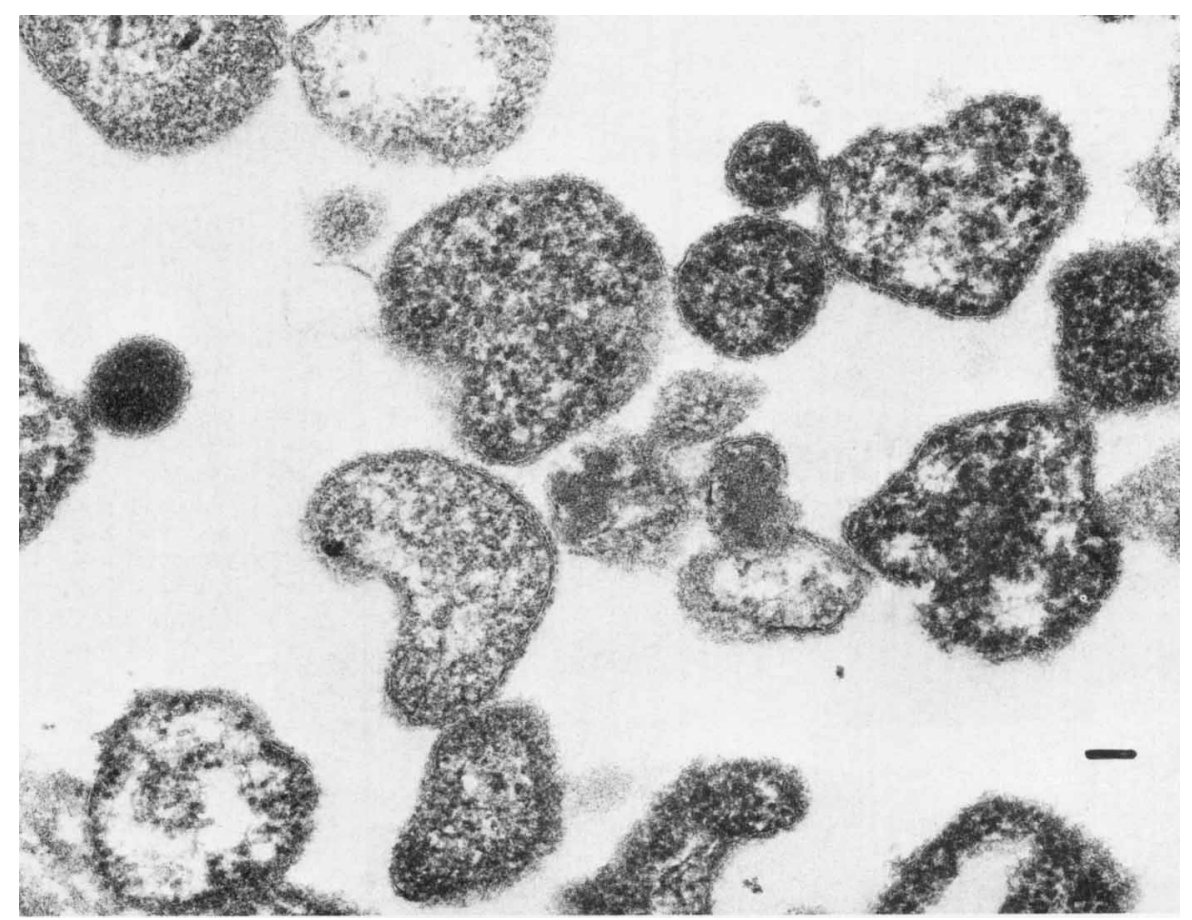

Fig. 4. Electron micrograph of a thin-section preparation of strain $383 \mathrm{C} . \times 50,000$. Bar equals $100 \mathrm{~nm}$. 
in media containing less than $2 \%$ serum. Growth improved as the serum concentration was increased up to $10 \%$. Growth occurred when rabbit, sheep, bovine, human, or guinea pig serum replaced the horse serum. Cholesterol was required for growth.

DNA base composition. The $\mathrm{G}+\mathrm{C}$ content of the DNA of strains $275 \mathrm{C}$ and $383 \mathrm{C}$ averaged $29 \mathrm{~mol} \%$. These estimates lie within the range of 25 to $35 \mathrm{~mol} \%$ as given by Hill (7) for mycoplasmas.

Metabolic reactions. Detailed testing by the methods of Aluotto et al. (2) indicated that strains $275 \mathrm{C}$ and $383 \mathrm{C}$ hydrolyzed arginine, did not reduce tetrazolium aerobically but did reduce it anaerobically, did not catabolize glucose or hydrolyze urea, and did not form film or spots. The results of other biochemical tests with these strains are given in Table 2.

Reactions with erythrocytes. Alpha hemolysis of the erythrocytes of sheep, cattle, horses, guinea pigs, chickens, rabbits, and humans (type A, Rh negative) was observed. Neither hemadsorption nor hemagglutination was observed.

Cultural properties. No growth was observed when cultures of the organism were incubated at 22 or $30 \mathrm{C}$. Growth occurred at 35,

TABLE 2. Summary of biochemical reactions and growth requirements of strains $275 \mathrm{C}$ and $383 \mathrm{C}$

\begin{tabular}{lc}
\hline \multicolumn{1}{c}{ Test } & Result \\
\hline Carbohydrate breakdown & \\
Glucose & - \\
Mannose & - \\
Maltose & - \\
Mannitol & - \\
Arabinose & - \\
Lactose & - \\
Raffinose & - \\
Xylose & - \\
Sucrose & - \\
Salicin & - \\
Sorbitol & - \\
Arginine hydrolysis & + \\
Urea hydrolysis & - \\
Tetrazolium reduction & $-a$ \\
Tellurite reduction & $-{ }^{a}$ \\
Film and spot production & - \\
Gelatin hydrolysis & - \\
Serum-slope digestion & - \\
Phosphatase & $+^{b}$ \\
Catalase & + \\
Oxidase & - \\
Methylene blue & Not reduced \\
SPS & Inhibits growth \\
Digitonin & Inhibits growth \\
Serum requirements & $2 \%$ \\
Cholesterol & Required \\
\hline
\end{tabular}

a Aerobic, negative; anaerobic, positive.

${ }^{b}$ After 14 days of incubation.
$37.5,40$, and $42 \mathrm{C}$. Titrations of broth cultures indicated that the optimum temperature is above $37.5 \mathrm{C}$ and close to $40 \mathrm{C}$. Cells of strains $275 \mathrm{C}$ and $383 \mathrm{C}$ were destroyed by heating at $50 \mathrm{C}$ for $15 \mathrm{~min}$ but not at $44 \mathrm{C}$ for $24 \mathrm{~h}$.

Filterability. The organism passed through $800-, 650-, 450-$, and $220-\mathrm{nm}$ filters with reduction of the initial broth titration $\left(1.8 \times 10^{7}\right)$ by $1,3,4$, and $6 \operatorname{logs}$, respectively. Since the organism passed through a 220 -nm filter, the test was repeated, and on this occasion the titer was reduced by 7 logs by the filter. Similar observations were made for strains $383 \mathrm{C}$ and 466 .

Serology. Two-way growth inhibition tests (GIT) between antisera and cultures of the described bovine strains, numbers 1 to 18 in Table 1 , failed to reveal cross-inhibition. No antiserum had less than a 2-mm zone of inhibition against the homologous antigen. Antisera against the remainder of the strains in Table 1 did not inhibit the growth of the test strains.

The serological results for strain $275 \mathrm{C}$ are supported by findings kindly made available by J. G. Tully, who found that this strain was not inhibited in the GIT by antisera against the strains listed in Table 1 or, in addition, those listed in Table 3 , with the exception of the strains of $M$. agalactiae, $M$. synoviae, $M$. ovipneumoniae, and strain 144P. The same tests were repeated for strain 466 by J. G. Tully, and

TABLE 3. Strains on which the growth-inhibition test was performed at $N^{\prime} H^{a}$

\begin{tabular}{|c|c|}
\hline Species & Strain \\
\hline Mycoplasma buccale & CH20247 \\
\hline M. faucium & DC-333 \\
\hline M. lipophilum & $\mathrm{MaBy}$ \\
\hline M. primatum & HRC 292 \\
\hline Mycoplasma sp. & (Monkey) HRC291 \\
\hline Mycoplasma sp. & (Goat) G145 \\
\hline Mycoplasma sp. & (Avian Group L) 694 \\
\hline Mycoplasma sp. & (Dog) MH5408 \\
\hline M. hyosynoviae & S16 \\
\hline$M$. gateae & Cat Mart \\
\hline Mycoplasma sp. & Calif. calf \\
\hline$M$. putrefaciens & $\mathrm{KS} 1$ \\
\hline Mycoplasma sp. & (Avian C) $33 F$ \\
\hline Mycoplasma sp. & (Avian D) 887 \\
\hline Mycoplasma sp. & (Avian F) 1197 \\
\hline Mycoplasma sp. & (Iowa 695 avian I complex) \\
\hline M. mycoides subsp. capri & PG3 \\
\hline$M$. capricolum & Calif. kid \\
\hline$M$. caviae & G122 \\
\hline M. suipneumoniae & $\boldsymbol{J}$ \\
\hline M. edwardii & PG24 \\
\hline M. cynos & H-831 \\
\hline M. molare & H-542 \\
\hline M. felis & Cat 27 \\
\hline M. feliminutum & Cat Ben \\
\hline Acholeplasma axanthum & $\mathrm{H} 86 \mathrm{~N}$ \\
\hline A. oculi & $19 \mathrm{~L}$ \\
\hline Acholeplasma sp. & D-1 (swine) \\
\hline Acholeplasma sp. & B-3046 \\
\hline Spiroplasma citri & Maroc \\
\hline
\end{tabular}

${ }^{a}$ National Institutes of Health, Bethesda, Md. 
the results were identical to those for strain 275C.

The antisera against strains of all of the recognized bovine species and strains $275 \mathrm{C}$, $383 \mathrm{C}$, and 466 gave satisfactory homologous titers in the metabolic-inhibition test (Table 4). Table 4 records the results of the heterologous tests between antigens $275 \mathrm{C}, 383 \mathrm{C}$, and 466 and antisera against strains of the recognized bovine species and the 22 other Mycoplasma and Acholeplasma species listed in Table 1 . The results of the converse test are given in Table 5.

Reciprocal growth-precipitation tests failed to reveal any cross-reaction between the test organisms and the glucose-catabolizing strains tested. There was either a one- or two-way cross between antigens $275 \mathrm{C}, 466$, and $383 \mathrm{C}$ or their antisera and the arginine-hydrolyzing strains of $M$. alkalescens, $M$. arginini, and $M$. gateae and their antisera (Table 6).

The results of the counterimmunoelectrophoresis study were similar to those noted for the growth precipitation test except that there was a complete two-way cross between the argininehydrolyzing mycoplasmas (Table 6). The presence of a common antigen in arginine-hydrolyzing strains of bovine mycoplasmas has been reported previously (5). Indirect fluorescent antibody tests (FAT) were positive at a dilution of
TABLE 5. Metabolic-inhibition tests with strains of recognized bovine species and other species of Mycoplasmatales against antiserum from strains $275 \mathrm{C}, 383 \mathrm{C}$, and 466

\begin{tabular}{|c|c|c|c|}
\hline \multirow[t]{2}{*}{ Mycoplasma strain tested } & \multicolumn{3}{|c|}{$\begin{array}{l}\text { Reciprocal metabolic-in- } \\
\text { hibition titers against an- } \\
\text { tisera to strain: }\end{array}$} \\
\hline & $275 \mathrm{C}$ & $383 \mathrm{C}$ & 466 \\
\hline \multicolumn{4}{|l|}{ Test strains: } \\
\hline $275 \mathrm{C}$ & 5,120 & 5,120 & 5,120 \\
\hline $383 \mathrm{C}$ & 2,560 & 5,120 & 5,120 \\
\hline 466 & 2,560 & 5,120 & 5,120 \\
\hline \multicolumn{4}{|l|}{$\begin{array}{l}\text { Strains of recognized bovine } \\
\text { species: }\end{array}$} \\
\hline $\begin{array}{l}\text { Mycoplasma mycoides } \\
\text { subsp. mycoides (PG1) }\end{array}$ & 10 & 10 & 10 \\
\hline M. bovigenitalium (PG11) & 10 & 10 & 10 \\
\hline $\begin{array}{l}\text { Acholeplasma laidlawii } \\
\quad \text { (PG8) }\end{array}$ & 10 & 10 & 10 \\
\hline M. bovirhinis (5M331) & 10 & 10 & 10 \\
\hline $\begin{array}{l}\text { M. agalactiae subsp. bovis } \\
\text { (Donetta) }\end{array}$ & 10 & 10 & 10 \\
\hline A. modicum (Squire) & 10 & 10 & 10 \\
\hline $\begin{array}{l}\text { Mycoplasma sp. (Group 7) } \\
\text { (N29) }\end{array}$ & 10 & 10 & 10 \\
\hline M. alkalescens (D12) & 10 & 10 & 10 \\
\hline M. dispar $(462 / 2)$ & 10 & 10 & 10 \\
\hline M. arginini (G 230) & 10 & 10 & 10 \\
\hline M. bovoculi (M 165/69) & 10 & 10 & 10 \\
\hline M. gateae (12PA) & 10 & 10 & 10 \\
\hline$M$. gallinarum (B142P) & 10 & 10 & 10 \\
\hline$M$. verecundum (107) & 10 & 10 & 10 \\
\hline \multicolumn{4}{|l|}{ Other species: } \\
\hline M. conjunctivae (M 164/69) & 10 & 10 & 10 \\
\hline M. gallisepticum (PG 13) & 10 & 10 & 10 \\
\hline
\end{tabular}

TABLE 4. Metabolic-inhibition tests of strains $275 C, 383 C$, and 466 by antisera to strains of recognized bovine species and other species of the order Mycoplasmatales

\begin{tabular}{|c|c|c|c|c|}
\hline \multirow{2}{*}{ Antiserum to: } & \multicolumn{4}{|c|}{ Reciprocal antiserum titers in metabolic-inhibition test against strain } \\
\hline & Homologous & $275 \mathrm{C}$ & $383 \mathrm{C}$ & 466 \\
\hline $275 \mathrm{C}$ & $>5,120$ & $>5,120$ & $>5,120$ & $>5,120$ \\
\hline $383 \mathrm{C}$ & $>5,120$ & 1,280 & $>5,120$ & $>5,120$ \\
\hline 466 & $>5,120$ & 2,560 & $>5,120$ & $>5,120$ \\
\hline \multicolumn{5}{|l|}{ Recognized bovine species: } \\
\hline $\begin{array}{l}\text { Mycoplasma mycoides subsp. mycoides } \\
\text { (PG1) }^{a}\end{array}$ & 320 & $10^{b}$ & 10 & 10 \\
\hline$M$. bovigenitalium (PG11) & 320 & 10 & 10 & 10 \\
\hline Acholeplasma laidlawii (PG8) & 160 & 10 & 10 & 10 \\
\hline M. bovirhinis (5M331) & 1,280 & 10 & 10 & 10 \\
\hline M. agalactiae subsp. bovis (Donetta) & 160 & 10 & 10 & 10 \\
\hline A. modicum (Squire) & 640 & 10 & 10 & 10 \\
\hline Mycoplasma sp. (Group 7) (N29) & 1,280 & 10 & 10 & 10 \\
\hline M. alkalescens (D12) & 2,560 & 10 & 10 & 10 \\
\hline$M$. dispar $(462 / 2)$ & 640 & 10 & 10 & 10 \\
\hline$M . \operatorname{arginini}(\mathrm{G} 230)$ & 640 & 10 & 10 & 10 \\
\hline M. bovoculi (165/69) & 1,280 & 10 & 10 & 10 \\
\hline M. gateae (12PA) & 640 & 10 & 10 & 10 \\
\hline$M$. gallinarum (B142P) & 2,560 & 10 & 10 & 10 \\
\hline$M$. verecundum (107) & 640 & 10 & 10 & 10 \\
\hline M. mycoides subsp. capri & $\mathrm{ND}^{r}$ & 10 & 10 & 10 \\
\hline M. synoviae & ND & 10 & 10 & 10 \\
\hline $\begin{array}{l}\text { Other Mycoplasma species as listed in Ta- } \\
\text { ble } 1\end{array}$ & $>160$ & 10 & 10 & 10 \\
\hline
\end{tabular}

${ }^{a}$ For sources of antisera used in these tests, see Table 1.

${ }^{b}$ All results are $\leqslant 10$.

c ND, Not done. 
TABLE 6. Other serological tests between strains of bovine species of Mycoplasmatales and their antisera

\begin{tabular}{|c|c|c|c|c|c|c|c|c|c|c|c|c|c|c|}
\hline \multirow{2}{*}{ Antigen } & \multicolumn{4}{|c|}{ Homologous antisera } & \multicolumn{3}{|c|}{$275 \mathrm{C}$ antiserum } & \multicolumn{3}{|c|}{$383 \mathrm{C}$ antiserum } & \multicolumn{4}{|c|}{466 antiserum } \\
\hline & GIT $^{x}$ & GP' $^{b}$ & CIEP & FAT $^{d}$ & GIT & GPT & CIEP & GIT & GPT & CIEP & GIT & GPT & CIEP & FAT \\
\hline $\begin{array}{l}\text { Mycoplasma mycoides subsp. } \\
\text { mycoides (PG1) }\end{array}$ & $+^{f}$ & + & + & & - & - & - & - & - & - & - & - & - & $\mathrm{ND}^{\circ}$ \\
\hline M. bovigenitalium (PG11) & + & + & + & + & - & - & - & - & - & - & - & - & - & - \\
\hline Acholeplasma laidlawii (P68) & + & + & + & + & - & - & - & - & - & - & - & - & - & - \\
\hline M. bovirhinis (5M331) & + & + & + & + & - & - & - & - & - & - & - & - & - & - \\
\hline $\begin{array}{l}\text { M. agalactiae subsp. bovis } \\
\text { (Donetta) }\end{array}$ & + & + & + & + & - & - & - & - & - & - & - & - & - & - \\
\hline A. modicum (Squire) & + & ND & + & + & - & - & - & - & - & - & - & - & - & - \\
\hline $\begin{array}{l}\text { Mycoplasma sp. (Group 7) } \\
\text { (N29) }\end{array}$ & + & + & + & + & - & - & - & - & - & - & - & - & - & - \\
\hline M. alkalescens (D12) & + & + & + & + & - & + & + & - & + & + & - & + & + & - \\
\hline M. dispar $(462 / 2)$ & + & + & + & & - & - & - & - & - & - & - & - & - & ND \\
\hline$M$. arginini $(\mathrm{G} 230)$ & + & + & + & & - & + & + & - & + & + & - & + & + & - \\
\hline M. bovoculi (M165/69) & + & + & + & & _ & _ & _ & - & - & - & - & - & - & ND \\
\hline M. gateae (12PA) & + & + & + & & - & + & + & - & + & + & - & + & + & ND \\
\hline M. gallinarum (B142P) & + & + & + & & - & - & - & - & - & - & - & - & - & ND \\
\hline$M$. verecundum (107) & + & + & + & & - & - & - & - & - & - & - & - & - & ND \\
\hline $275 \mathrm{C}$ & + & + & + & + & + & + & + & + & + & + & + & + & + & + \\
\hline $383 \mathrm{C}$ & + & + & + & & + & + & + & + & + & + & + & + & + & + \\
\hline 466 & + & + & + & & + & + & + & + & + & + & + & + & + & + \\
\hline
\end{tabular}

aIT, Growth-inhibition test.

- GPT, Growth-precipitation test.

c CIEP, Counterimmunoelectrophoresis.

${ }^{d}$ FAT, Fluorescent-antibody test-direct.

FAT, Fluorescent-antibody test-indirect.

$f+$, Positive.

ND, Not done.

$1 / 160$ when antisera against strain 466 was reacted with strains $275 \mathrm{C}$ and $383 \mathrm{C}$. There was no reaction with the eight other bovine species listed in Table 6. Direct FAT using the heterologous conjugated antisera listed in column 1, Table 6, did not react with the three tests strains. Conjugated strain 275 antisera reacted with strains $383 \mathrm{C}$ and 466 but not against the heterologous bovine species listed in Table 6 .

Growth- and metabolic-inhibition tests and growth-precipitation tests proved that at least 27 other arginine-hydrolyzing strains of $\mathrm{Myco}$ plasma isolated at the Animal Diseases Research Institute (Western) from semen, preputial washings, and cervico-vaginal mucus are similar to the isolates studied. Previous preliminary studies (15) reported that a serologically identical organism had been recovered from the milk, joint, and umbilicus of a calf, the vaginal mucus of a cow (8), and from the semen and preputial washings of bulls in Ontario.

\section{DISCUSSION}

The observed morphological, physical, and cultural characteristics of the test strains are consistent with those regarded as defining membership in the order Mycoplasmatales (17). The serum and cholesterol requirements place these strains in the family Mycoplasmataceae. By the growth-inhibition, metabolic-inhibition, growth-precipitation, and fluorescent-antibody tests, the strains were found to be antigenically homogeneous and serologically different from the 67 characterized and uncharacterized members of the order Mycoplasmatales listed in Tables 1 and 3 . Therefore, we regard strains $275 \mathrm{C}$, $383 \mathrm{C}$, and 466 as belonging to a new species, for which we propose the name Mycoplasma canadense (can. a. den'se. M. L. adj. canadensis pertaining to Canada).

The following is a summary description of $M$. canadense sp. nov.

Morphology and staining characteristics. Minute coccoid and bipolar elements with ring and other pleomorphic forms are visible by staining. Gram-negative, but counter-stain weakly. The cells are bounded by a triple-layered cell membrane.

Size and filtration characteristics. Cells are approximately 250 to $600 \mathrm{~nm}$ in diameter, as determined by electron microscopy. Viable particles are filterable through a filter with a 450$\mathrm{nm}$ pore diameter but are largely retained by a filter with a $220-\mathrm{nm}$ pore diameter.

Oxygen requirements. Aerobic, microerophilic, and anaerobic.

Agar colonies. Colonies on horse serum agar are 80 to $150 \mu \mathrm{m}$ in diameter and possess the typical "fried-egg" appearance with growth down into the agar.

Liquid cultures. Slightly turbid. 
Film and spots. Film and spots are not formed on horse serum agar or egg yolk emulsion agar.

Biochemical reactions. Arginine, but not urea, is hydrolyzed. Glucose, mannose, mannitol, arabinose, lactose, raffinose, xylose, sucrose, salicin, and sorbitol are not utilized. Tetrazolium salts and tellurite were not reduced aerobically, but they were reduced anaerobically.

Temperature requirements. Optimum, $37 \mathrm{C}$ to $40 \mathrm{C}$. No growth at $30 \mathrm{C}$ or lower. Cells are not viable after $15 \mathrm{~min}$ at $56 \mathrm{C}$.

Hemadsorption and hemagglutination. Neither hemadsorption nor hemagglutination was observed with horse, sheep, human, rabbit, guinea pig, or chicken erythrocytes.

Hemolysis. Alpha hemolysis occurred with erythrocytes from horses, cows, sheep, humans (type A, Rh negative), rabbits, chickens, and guinea pigs.

Antigenic structure. The type strain was antigenically distinct from strains of the Mycoplasma species and subspecies with which it was compared by growth-inhibition and/or metabolic-inhibition tests. It was antigenically distinct from the glucose-catabolizing strains of bovine origin, but it shared antigens with all of the bovine arginine-hydrolyzing strains tested, with the exception of the strain of $M$. gallinarum, by the growth-precipitation and counterimmunoelectrophoresis tests.

Pathogenicity. Causes mastitis and possibly other conditions.

Source. The three strains reported were recovered from the reproductive tracts of cattle, from the mastitic udder of a cow, and from a joint and the umbilicus of a calf.

Habitat. Uncertain.

Type strain. Strain 275C. This strain has been deposited in the National Collection of Type Cultures, Central Public Health Laboratory, London, England, under the number 10152 .

\section{ACKNOWLEDGMENTS}

We thank J. G. Tully for his serological comparison of strain $275 \mathrm{C}$ with the recognized species of Mycoplasma and Acholeplasma and for his assistance to H. L. Ruhnke during her comparison of strain 466 to other members of the order Mycoplasmatales at the National Institutes of Health. We also wish to express our thanks to Patricia A. Brown and Jack Burchak for excellent technical assistance; to Susi Becker for the electron microscopy performed at the Animal Diseases Research Institute (E); to L. Niilo and K. Jericho for photographs of colonies; and to S. E. Magwood for his encouragement throughout this study and for his helpful advice in the preparation of this paper.

\section{REPRINT REQUESTS}

Address reprint requests to: Dr. E. V. Langford, Agriculture Canada, Animal Diseases Research Institute (Western), P.O. Box 640, Lethbridge, Alberta, Canada T1J 3Z4.

\section{LITERATURE CITED}

1. Al Aubaidi, J. M., and J. Fabricant. 1971. Characterization and classification of bovine mycoplasma. Cornell Vet. 61:490-518.

2. Aluotto, B. C., R. G. Whittler, C. O. Williams, and J. E. Faber. 1970. Standardized bacteriologic techniques for the characterization of Mycoplasma species. Int. J. Syst. Bacteriol. 20:35-58.

3. Cho, H. J., and E. V. Langford. 1974. Rapid detection of bovine mycoplasma antigens by counterimmunoelectrophoresis. Appl. Microbiol. 28:897-899.

4. Del Guidice, R. A., R. H. Purcell, T. R. Carski, and R. M. Chanock. 1974. Mycoplasma lipophilum sp. nov. Int. J. Syst. Bacteriol. 24:147-153.

5. Ernø, H., and K. Jurmanova. 1973. Bovine mycoplasmas: serological studies by double immunodiffusion, growth precipitation and growth inhibition. Acta Vet. Scand. 14:524-537.

6. Fabricant, J., and E. A. Freundt. 1967. Importance of extension and standardization of laboratory tests for identification and classification of mycoplasma. Ann. N.Y. Acad. Sci. 14:50-58.

7. Hill, L. R. 1966. An index to deoxyribonucleic acid base compositions of bacterial species. J. Gen. Microbiol. 44:419-437.

8. Langford, E. V. 1975. Mycoplasma species recovered from the reproductive tracts of Western Canadian Cows. Can. J. Comp. Med. 39:113-118.

9. Langford, E. V., and R. H. Leach. 1973. Characterization of a mycoplasma isolated from infectious bovine keratoconjunctivitis $M$. bovoculi sp. nov. Can. J. Microbiol. 19:1435-1444.

10. Marmur, J. 1961. A procedure for the isolation of deoxyribonucleic acid from micro-organisms. J. Mol. Biol. 3:208-218.

11. Purcell, R. H., D. Taylor-Robinson, D. C. Wong, and R. M. Chanock. 1966. A colour test for the measurement of antibody to the nonacid-forming human mycoplasma species. Am. J. Epidemiol. 84:51-66.

12. Razin, S. 1969. Structure and functions in mycoplasmas. Annu. Rev. Microbiol. 23:317-356.

13. Rosendal, S. 1974. Mycoplasma molare, a new canine Mycoplasma species. Int. J. Syst. Bacteriol. 24:125130.

14. Rosendal, S., and F. T. Black. 1972. Direct and indirect immunofluorescence of unfixed and fixed mycoplasma colonies. Acta. Pathol. Microbiol. Scand. Sect. B 80:615-622.

15. Ruhnke, H. L., and O. Onoviran. 1975. Isolation of an apparently new species of Mycoplasma from cattle. Vet. Rec. 96:203.

16. Somerson, N. L., D. Taylor-Robinson, and R. M. Chanock. 1963. Haemolysin production as an aid in the identification and quantitation of the Eaton agent (Mycoplasma pneumoniae). Am. J. Hyg. 77:122-128.

17. Subcommittee on the Taxonomy of Mycoplasmatales. 1972. Proposal for minimal standards for descriptions of new species of the order Mycoplasmatales. Int. J. Syst. Bacteriol. 22:184-188.

18. Taylor-Robinson, D., R. H. Purcell, D. C. Wong, and R. M. Chanock. 1966. A colour test for the measurement of antibody to certain mycoplasma species based upon the inhibition of acid production. J. Hyg. 64:91104. 